\title{
THE POLITICS OF PARALLEL PENSIONS: LESSONS FROM THE UNITED KINGDOM FOR THE UNITED STATES
}

\author{
R. Kent Weaver \\ CRR WP 2006-7 \\ Released: February 2006 \\ Draft Submitted: December 2005 \\ Center for Retirement Research at Boston College \\ 550 Fulton Hall \\ 140 Commonwealth Ave. \\ Chestnut Hill, MA 02467 \\ Tel: 617-552-1762 Fax: 617-552-0191 \\ http://www.bc.edu/crr
}

* R. Kent Weaver is Professor of Public Policy and Government at Georgetown University and a Senior Fellow in Governance Studies at The Brookings Institution. The research reported herein was performed, in part, pursuant to a grant from the U.S. Social Security Administration (SSA) funded as part of the Retirement Research Consortium. The findings and conclusions expressed are solely those of the author and do not represent the views of SSA, any agency of the Federal Government, Georgetown University, Boston College or The Brookings Institution.

(C) 2006, by R. Kent Weaver. All rights reserved. Short sections of text, not to exceed two paragraphs, may be quoted without explicit permission provided that full credit, including (C) notice, is given to the source. 


\section{About the Center for Retirement Research}

The Center for Retirement Research at Boston College, part of a consortium that includes a parallel centers at the University of Michigan and the National Bureau of Economic Research, was established in 1998 through a grant from the Social Security Administration. The goals of the Center are to promote research on retirement issues, to transmit new findings to the policy community and the public, to help train new scholars, and to broaden access to valuable data sources. Through these initiatives, the Center hopes to forge a strong link between the academic and policy communities around an issue of critical importance to the nation's future.

\section{Center for Retirement Research at Boston College \\ 550 Fulton Hall \\ 140 Commonwealth Ave. \\ Chestnut Hill, MA 02467 \\ phone: 617-552-1762 fax: 617-552-0191 \\ e-mail: crr@bc.edu \\ http://www.bc.edu/crr}

\section{Affiliated Institutions:}

American Enterprise Institute

The Brookings Institution

Center for Strategic and International Studies

Massachusetts Institute of Technology

Syracuse University

Urban Institute 


\section{Policy Abstract}

Opt-out pensions pose many difficult design and implementation issues. The U.K. experience suggests several valuable lessons for U.S. policymakers. First, complex interactions between public and opt-out pensions may create confusion among workers, leading to both discontent and demands for policy change. Second, allowing recurrent opportunities to opt into and out of individual accounts increases administrative complexity, increases choice complexity for workers, and may undermine system legitimacy_but it may also be politically unavoidable. Third, the market may not, unprompted, provide personal pension vehicles that are appropriate retirement savings vehicles for low-earners, especially those who have interrupted earnings records. Fourth, price indexation of wage histories may create pressures for ad hoc policy change. Fifth, increased reliance on means-tested pensions increases administrative complexity and creates perverse incentives for savings and for types of assets held, especially where assets as well as income-tests are involved. Sixth, an option for quasi-privatized pensions leads to pressures to treat those pensions more like fully private pensions with respect to flexibility in withdrawals, inheritability, and ability to borrow against fund balances. Seventh, annuitization costs can add significantly to pension system costs and inequality across cohorts, so the state may want to take on the role of monopoly annuity provider. Eighth, scandals and failures drive policymakers and consumer responses, so it is important to get the policy design right the first time and invest heavily in public understanding of how the reform will work. A final lesson is that scandals, policy tinkering, and uncertainty over pension policy may affect workers' propensity to opt out of state pensions in unpredictable ways - not just driving people to exit from the state system. 


\begin{abstract}
The public pension system in the United Kingdom is unusual in several ways, most notably in having an earnings-related pension tier in which private providers operate in parallel with (as an opt-out from) the state system rather than as an additional tier. As a result of widespread opting-out, the U.K. ranks very low among OECD countries both in terms of current pension expenditures and its anticipated long-term pension expenditure burden. British pension policy has also been characterized by frequent tinkering, however, especially regarding rules governing the interaction between the state earningsrelated pension and private alternatives. This paper argues that British pension policy has been driven by the policy legacy of a very late move toward earnings-related public pensions and strong pressure to restrain public spending that the current Labour government inherited from its Conservative predecessor. The result has been a pension system that ranks fairly highly in terms of affordability for government but poorly on most other measures, including clarity for workers and recipients, riskiness for workers, administrative effectiveness and efficiency, encouraging continued employment for older workers, and macro-economic efficiency.
\end{abstract}




\section{Introduction}

The public pension system in the United Kingdom is distinctive among the advanced industrial countries in several ways. One is the unusual relationship between the state and private pension sectors. The U.K. has a quasi-universal flat-rate state pension. On top of this basic pension is an earnings-related pension tier in which private providers operate in parallel with (as an opt out from) the state system rather than as an additional tier. Second, as a result of widespread opting-out, the U.K. ranks very low among OECD countries both in terms of current pension expenditures and its anticipated long-term pension expenditure burden. A third characteristic of British pensions is frequent tinkering with public pensions, especially rules governing the interaction between the state earnings-related pension and private alternatives. A fourth critical dimension of British pension policy is a prolonged pattern of what Jacob Hacker has called "policy drift" in private occupational pensions away from defined benefit to defined contribution principles. ${ }^{1}$ A fifth and final characteristic of British pension policy is the very high level of seniors who are eligible for means-tested pensions.

The purpose of this paper is to draw out lessons from the U.K. experience for the United States, with a particular emphasis on design and implementation of a parallel “partial opt-out” pension system. While different programmatic histories and political environments mean that few lessons (either positive or negative) can be directly

\footnotetext{
${ }^{1}$ See Jacob S. Hacker, The Divided Welfare State: The Battle over Public and Private Social Benefits in the United States. Cambridge University Press, 2002, and Hacker, "Privatizing Risk without Privatizing the Welfare State: The Hidden Politics of Social Policy Retrenchment in the United States," American Political Science Review 98: 2 (May 2004): 243-60.
} 
transferred from one country to the other, the British experience does suggest a number of cautions and opportunities for U.S. policymakers.

I argue in the paper that in addition to the usual demographic and fiscal pressures facing most of the advanced industrial countries, two distinctive forces have driven pension politics in the United Kingdom. First is the policy legacy of a very late movein the 1960s and 1970s - to a public earnings-related pension system. In a classic example of path dependence, the new earnings-related pension system was created to fit alongside, rather than pre-empting or supplanting, a very large pre-existing private (both occupational and personal) pension sector. The late development of state earningsrelated pensions had the simultaneous effects of (1) lowering the overall costs of the public pension system, (2) making issues concerning low-income recipients far more visible, and making it more difficult to hide cross-subsidies from upper to lower income groups within a broader pension system, and (3) creating persistent problems with how to integrate the public and private earnings-related schemes and how much (if at all) to allow switching back and forth between those systems.

Second, the long period of Conservative political hegemony under Margaret Thatcher and John Major reinforced persistent pressures to keep government expenditures down in ways that changed the character of pension options and discourse, enhancing the attractiveness of privatized pensions for the "New Labour" government since 1997.

\section{THE SOCIAL AND ECONOMIC ENVIRONMENT}


Most continental European countries face a very severe deterioration in their ratio of individuals of working age to those aged 65 plus in coming years. The situation in the United Kingdom is somewhat less dramatic, with the ratio of those aged 65 plus to those aged 20-64 likely to rise from a little under 30 percent in the year 2000 to almost 50 percent in 2050. While a falling youth dependency ratio (due to fertility rates that are well below replacement) will lower the total (youth plus $65+$ ) dependency ratio somewhat, it is still expected to increase from a historical low in the first decade of the 21 st Century (under 70 percent) to about 85 percent by $2040 .^{2}$

Like most other West European countries, the U.K also has relatively low rates of labor market participation by older workers. Almost a third of men and a slightly higher percentage of women between the ages of 50 and the standard pensionable age are not employed. ${ }^{3}$ Early labor market withdrawal is especially prevalent among women, who have historically been able to collect a full state pension at age 60 (this will be equalized with the state pension age for men between 2010 and 2020, as will be discussed below). ${ }^{4}$

\section{THE INSTITUTIONAL AND POLITICAL ENVIRONMENT}

\footnotetext{
${ }^{2}$ Pensions Commission, Pensions: Challenges and Choices, Her Majesty's Stationery Office, 2004, Figures 1.6 and 1.7. See more broadly chapter 1 for a discussion of the demographic assumptions underlying these projections. In comparative terms, with the ratio of those aged 65 plus to those aged 15-64 in Britain is likely to rise only from 24.4 per 100 in the year 2000 to 39.2 in 2050 - a bit lower than in Canada (40.9) and significantly higher than in the United States (34.2), but much lower than in most West European countries. Department for Work and Pensions, Her Majesty's Treasury, and Inland Revenue, Simplicity, Security and Choice: Working and Saving for Retirement, London: Her Majesty's Stationery Office, Cm 5677, December 2002, p. 16.

${ }^{3}$ After a major decline in the percentage of men between 50 and the standard pension age who are employed between the early 1970s and early 1990s, and fairly stable rates in that period among women, employment rates among both men and women in this age group have risen modestly over he last decade. Pensions Commission, Pensions: Challenges and Choices, Figures 2.9-2.12.

${ }^{4}$ Department for Work and Pensions, Her Majesty's Treasury, and Inland Revenue, Simplicity, Security and Choice, p. 17.
} 
The United Kingdom is a parliamentary system with a House of Commons elected by First-past-the-post (otherwise known as single member plurality) electoral rules and an extremely weak appointed/hereditary second chamber. Institutional theorists suggest that this combination of electoral rules and weak inter-branch and inter-chamber checks and balances is likely to give rise to a political dynamic in which (1) two large political parties dominate national politics, (2) those parties generally pursue policies close to the preference of median voters, (3) one of the two major parties generally holds power in single-party majority governments despite winning only a plurality of the popular vote, (4) the two major parties alternate in power with some regularity, but (5) occasional major swings in policy are possible after elections when the two parties have deviated from the preferences of median voters. ${ }^{5}$

The U.K. hews to these expectations in some regards, but deviates in others. The party winning a plurality of the popular vote in the U.K. has almost always been rewarded with a hefty bonus in seat shares. Thus single-party majority governments have been the norm: only once since World War II, in February 1974, has a single party failed to secure a majority of seats in the House of Commons - and that government lasted less than a year until new elections were called. ${ }^{6}$ While smaller parties have been persistent niche players in the British system (most notably the Liberals, and more recently the

${ }^{5}$ On plurality electoral rule effects, see for example Duverger, Political Parties: Their Organization and Activity in the Modern State, London: Methuen, 1963, and Bernard Grofman and Arend Lijphart, eds., Electoral Laws and their Political Consequences: New York, Agathon, 1986. On concentration of power and policy stability, see R. Kent Weaver and Bert Rockman, Do Institutions Matter? Washington, D.C.: The Brookings Institution, 1993.

${ }^{6}$ However, in two additional elections of the last nine - those of 1964 and October 1974, the governing party's parliamentary majority did not last the full duration of Parliament because of by-election losses. See Dennis Kavanaugh, "Elections," in Bill Jones et al, Politics UK [fourth edition], Harlow, Essex: Longmans, 2000, pp.143-161 at pp. 149150. 
Liberal Democrats), the logic of plurality elections has meant that such parties have been rewarded with a much smaller share of seats than votes.

Unlike what such theories suggest, however, the two big parties in the party system have not persistently hugged the center of the political spectrum, seeking to become virtually ideology-less "catch-all" parties slavishly pursuing the median voter. There is some truth to such a characterization in the first decades of the post-war-period: it even had a label, "Butskellism" (a combination of the surnames of successive Labour and Conservative Chancellors of the Exchequer), used to describe an agreement on Keynesian economic management, full employment, a substantial welfare state, and a significant role for government ownership. ${ }^{7}$ But this uneasy accommodation was already fraying by the late 1960s, fuelled by Britain's continued relative economic decline, inflation, and heightened trade union militancy. ${ }^{8}$

In the 1970s, the two major British parties, Labour and the Conservatives, moved far away from accommodation and from the median voter. The reasons for this deviation are inevitably complex, but at least two such forces are clear within the Labour Party: powerful trade union blocs within the Labour Party and left-wing party activists both exerted powerful (and often conflicting) tugs away from the center that were felt with increasing strength in the late 1960s. ${ }^{9}$ This in turn allowed Conservatives to deviate from

\footnotetext{
${ }^{7}$ See Brendan Evans, Thatcherism and British Politics 1975-1999, Gloucestershire: Sutton, 1999, chapter 1.

${ }^{8}$ For an interpretation emphasizing the degree of consensus politics in this period, see Dennis Kavanaugh, The Reordering of British Politics: Politics After Thatcher, Oxford: Oxford University Press, 1997, chapters 2-5. For an interpretation focusing on the remaining disagreements between the Conservatives and Labour, see Howard Glennerster, British Social Policy Since 1945 [second edition] Oxford: Blackwell, 2000, chapter 4.

9 See for example George Tsebelis, Nested Games: Rational Choice in Comparative Politics, Berkeley and Los Angeles: University of California Press, 1990, chapter 5.
} 
the center as well - a move favored by many party activists, and by Margaret Thatcher, Conservative leader from 1977 to 1990 — and still enjoy electoral success, so long as they were perceived by voters to be less extreme on the right than Labour was on the left. Fortunately for the Conservatives, Labour was extremely accommodating in this regard through the mid-1980s. ${ }^{10}$

As a result, the U.K. did not experience regular alternations in power in the last two decades of the twentieth century. Divisions within the center and left parties gave the Conservatives an uninterrupted 18 year run in power from 1979 to 1997 while never winning more than 44 percent of the popular vote. The absence of party change in government lowered the risk that pension policy would be subject to frequent reversals of direction, while Labour's weakness lowered the risk that the Conservatives would have to engage in pension "bidding wars" at election time. Equally important, Conservative dominance meant that the Thatcher government's stress on an increased role for private pension provision had an opportunity to become fully institutionalized and build up a strong support constituency among both pension providers and holders of privatized pensions. By the time that a chastened Labour Party_ “or New Labour" as Prime Minister Tony Blair likes to call it—came back into power with a smashing victory in 1997, it was firmly pursuing a centrist line, and had adopted many Thatcherite positions, including acceptance of a greater role for private rather than state-provided pensions. But while the U.K. avoided major reversals in policy direction after the mid 1980s, the absence of veto points characteristic of the Westminster parliamentary system also meant that single-party majority governments could engage in frequent tinkering at the margins

${ }^{10}$ Indeed, in 1981, a group of centrist Labour MPs abandoned the party for a new (an illfated) Social Democratic Party, which eventually merged with the Liberals to form the Liberal Democrats. 
to address perceived shortcomings in the pension system. As we will see below, frequent tinkering with pensions has characterized both the Thatcher and Blair eras-a major difference from the United States, where have been hardly any significant changes in Social Security legislation since 1983.

\section{THE PENSION POLICY ENVIRONMENT}

As in other countries, pension politics in the U.K., and in particular the opportunities for pension retrenchment, have been heavily influenced by the legacies of past policy choices. In the case of the U.K., that legacy is dominated by the relatively late arrival of a public earnings-related pension program. In 1908, a Liberal government created a non-contributory means-tested-pension payable at age 70 - although outside the old system of poor relief. ${ }^{11}$ For most of the next seven decades, British politicians and labor leaders engaged in a long debate over whether pensions should be contributory or non-contributory, paid at a flat rate or earnings related, and universal or limited in coverage. In 1926, a contributory, non-means-tested pension was introduced. The next major development was the 1946 National Insurance Act, passed by the U.K.'s postwar Labour government in the wake of the wartime Beveridge Report on Social Insurance and Allied Services. Although Basic Pension benefits were not means-tested, they were paid at a very low flat rate - in part because until 1975 eligibility was established through flat-rate weekly contributions, which could not be higher than low-wage workers could afford. Since 1975 Basic Pension contributions have been financed as part of National Insurance contributions as a percentage of income between lower and upper income

11 For a discussion, see Hugh Heclo, Modern Social Politics in Britain and Sweden: From Relief to Income Maintenance: New Haven and London: Yale University press, 1974, pp. 158-178. 
thresholds. And contrary to Beveridge's proposal—but similar to pension schemes in many other OECD countries - the new higher pensions were made payable immediately rather than after a twenty year transitional period.

Even the basic state pension in the U.K. requires a high level of labor force participation at a significant wage in order to receive full benefits. People who earn less than the "lower earnings limit" ( $£ 3,900$, or around $\$$ US6,200 in 2002/3), do not have to pay National Insurance contributions, but neither do they accrue credits toward a full Basic Pension unless they have received certain benefits or had specified caregiver responsibilities during that year. ${ }^{12}$ Men have to have contributions for 44 years and women for 39 years in order to qualify for a full pension (the figures are gradually being equalized as women's retirement age is being raised to equal that for men), with some provision since 1978 for years speny in caregiving. Thus women who spend a substantial number of years out of the labor force as caregivers for children or parents were particularly likely to end up with less than a full Basic Pension..$^{13}$ In 1998, for example, 86 percent of men but only 49 percent of women qualified for a full Basic Pension on the basis of their earnings. ${ }^{14}$ This combined with the relatively low level of the Basic

\footnotetext{
${ }^{12}$ Those who earn between $£ 3,900$ and $£ 4,615$ (the "primary threshold" in 2002/2003 do not actually pay National Insurance contributions but are credited with them. Pensions Service, State Pensions: Your Guide, The Pension Service, October 2002, p.3.

${ }^{13}$ For general information on qualifications for the Basic State Pension, see Age Concern, The State Pension, Fact Sheet 19, FS/19/03/04/01 AM005, April 2003. In addition, up until 1977, married women had the option of paying the "married woman's stamp," which lowered their National Insurance contribution but did not entitle them to Basic Pension rights independent of their husband. Women already paying the lower rate were allowed to continue to do so after 1977. Sarah Ross, "Big Challenges for Low-Paid, Part Timers, Financial Times [London edition], September 21, 2002, FT Money, p. 3; Stephen Womack, "Plight of the 4.5 million Women Trapped by 'Biggest Pension Scandal Ever," Mail on Sunday, September 8, 2002 p. 26.

${ }^{14}$ Secretary of State for Social Security, A New Contract for Welfare: Partnership in Pensions, Cm. 4179, December 1998, p. 18. Those who have less than 25 percent of the
} 
Pension, meant that many pensioners in the U.K. have remained eligible for means-tested benefits.

The flat-rate character of benefits (and for many years, flat-rate contributions as well) in the Basic State Pension had important implications for the future of the British pension system, as a number of scholars have noted. ${ }^{15}$ Middle and upper income groups sought a greater degree of pension provision than the state pension could provide. In the absence of agreement on a public earnings-related tier, both a large occupational (employer-based) and a smaller individual pension sector catering to upper-income Britons arose in the U.K.

The other major element of the British state pension system in the past quarter century has been the State Earnings-Related Pension Scheme (SERPS), enacted by a Labour government in 1975 after prolonged wrangling (the Heath government had passed a different scheme in 1973 that did not come into effect after the Conservatives' loss in the February 1974 election). When fully phased in, SERPS was to provide a benefit based on one-quarter of earnings between the Lower and Upper Earning Limits in the best twenty years of employment. Thus it was especially generous to those who spent a substantial time out of the labor force, and to the transitional generation as the program was phased in. Post retirement benefits were guaranteed to increase at least in line with

years required for a full basic pension get nothing, while those who have more than the minimum but not enough for a full Basic Pension receive a pro-rated amount. There is also a non-contributory pension for people aged 80 and over. See Pensions Service, State Pensions: Your Guide, p. 6.

${ }^{15}$ See for example Esping Anderson, Pierson, Bonoli; and Helen Fawcett, "The Privatization of Welfare: The Impact of Parties on the Public/Private Mix in Pension Provision," West European Politics, vol. 18, no. 4 (October 1995) pp. 150-169. 
prices. ${ }^{16}$ As we will see later, however, SERPS has been repeatedly altered-and recently renamed and reconstituted-since its introduction.

Another central policy legacy in the British pension system has been the absence of a truly dedicated payroll tax mechanism for pensions. While the British National Insurance scheme has always had separate National Insurance contributions, there has always been a Treasury contribution to National Insurance benefits, and the British Treasury has consistently viewed a real earmarking of dedicated taxes as anathema because it interferes with their capacity to manage overall government expenditures. Moreover, contrary to Beveridge's desire for a system of advanced funding, Basic Pension benefits under the 1946 Act were paid out immediately. As a result, (1) there was a weak link between both overall and individual contributions and benefits; and (2) no tradition of advanced funding of pensions in a dedicated fund (not even a fund consisting of IOUs in the form of government securities) ever developed in the U.K.

A third key legacy of the low level of publicly provided pension benefits in the U.K. was the strong emergence of occupational pensions. Occupational schemes covered about 37 percent of the workforce by 1956 and 49 percent of the labor force thereafter-a figure that remained relatively steady at around half of the labor force for the next twenty years. ${ }^{17}$ Pension providers, in turn, developed into a substantial force that would have to be accommodated in later reforms that aimed to provide an earnings-related pension. Unlike in Sweden, where company pension schemes pre-existing the state earnings related pension were integrated with and became supplementary to the state program, in

${ }^{16}$ For a brief review of the structure of SERPS, see Secretary of State for Social Services, Reform of Social Security, London: Her Majesty's Stationery Office, Cmnd 9517, vol 3, pp. 2-3.

${ }^{17}$ Secretary of State for Social Services, Reform of Social Security, London: Her Majesty's Stationery Office, Cmnd 9517, vol 1, p. 21. 
the U.K., occupational pensions became an alternative to SERPS. Occupational pensions that met specified criteria were allowed to "opt out" of SERPS, receiving a rebate of part of National Insurance contributions that would be used to support the occupational pension scheme. In the original program rules, only "final salary schemes"occupational pensions that provided a defined benefit — with benefits roughly equivalent to those under SERPS, were allowed to contract out. But the government provided an inflation protection guarantee for contracted-out occupational pensions as well as SERPS pensions.

Opt-out provisions for SERPS had a number of important consequences for the program. On the fiscal side, contracting out meant that state pension obligations in the U.K. would be far lower than in many other countries. Indeed, public pension expenditures in the U.K. are actually expected to decline as a percentage of GDP from an already relatively low 5.5 percent of GDP in 2000 to 4.4 percent by 2050 -less than one third the level projected for many West European countries. ${ }^{18}$

Allowing an opt-out from the second tier of the state pension system also created a number of recurring policy issues for the program, however. How much of a rebate should contracted-out pension plans receive from National Insurance contributions, for example? How could occupational pensions be offered in a way that did not (1) unduly restrict labor mobility between firms or penalize workers too severely if they changed employers, (2) expose employers to unsustainable pension burdens, especially in industries where the number of workers declined over time, and (3) expose workers to

${ }^{18}$ Budgetary Callenges Posed by Ageing Populations, EPC/ECFIN/655/01-EN final, Table 3.5, reproduced in U.K. House of Commons, Works and Pensions Committee, The Future of U.K. Pensions, HC-92-1, Third Report of Session 2002-03, Volume 1: Report and Proceedings of The Committee, London: the Stationery Office Limited, April 12, 2003. 
too high a risk of losing accumulated pension rights if their employers became insolvent? And how much choice, if any, should employees have between their employer's occupational pension and SERPS? Contracting-out had important political consequences as well: it meant that SERPS was a program in which many workers and retireesincluding many manual workers who were the natural constituency of the Labour Partydid not perceive themselves as having a strong personal stake in state pensions.

Finally, the extremely complex pension system in the U.K. also had led to relatively high levels of senior poverty and levels of income inequality among British seniors in comparison to most other wealthy OECD countries. In particular, the shift from indexing the basic State Pension by the higher of wage and price growth to indexing by inflation instituted early in Margaret Thatcher's period in power (and discussed further below) meant that those dependent primarily on the flat-rate pension fell increasingly behind wage earners.

Growing concern over senior poverty, in turn, has had a major impact on the British pension agenda in recent years. Since the advent of the Blair government in 1997, government has struggled with the question of whether it is best to address senior poverty through a more generous Basic State pension, a restructured SERPS, an income-tested program, or changes to private pensions that make them a better deal for low-wage earners and those who spend a large part of their adult lives as caregivers.

\section{THE INTEREST GROUP ENVIRONMENT}

Interest group activity on pensions in the U.K. has been heavily influenced by the policy legacy of a heavily privatized pension system that operates parallel to and in 
partial competition with state pensions rather than as a supplement to them. In most OECD countries, pension politics has generally pitted trade unions and (more recently) seniors organizations against rather more diffuse business interests opposed to higher payroll taxes. The complex British pension system has given rise to an equally complex set of interest groups, in which the interests of provider organizations have generally had more influence than trade unions, and organizations of pensioners have had difficulty speaking with a single voice.

A number of organizations focused on concerns of the aged do exist in the U.K. While these organizations do lobby and participate in pension policy consultations organized by the government, they are generally not major players in British pension policy. Two of the longest-established organizations, Age Concern and Help the Aged, are primarily social service organizations that provide services such as day care and transportation for the aged, often on a contractual basis with funding from local governments. These organizations also rely heavily on charitable contributions for funding and on volunteers for providing services. While Help the Aged does have a small policy unit, its efforts are spread thin between a variety of issues such as transport, housing and age discrimination as well as pensions.

Several newer organizations have taken a more overtly political role. The National Pensioners' Convention was originally established in 1979 by the Trades Union Congress, Age Concern and Help the Aged to represent pensioners. But with a tiny central office staff of less than ten, all volunteers, the NPC cannot hope to match the analytic capacity of pension providers. 
The Association of Retired Persons/Over 50s was founded more recently, in 1988. Modeled on the American Association of Retired Persons, ARP/O50 is a membership organization claiming a membership of more than 100,000 (from a potential membership of 18 million Britons over age 50) in the millenium year. ARP/O50 lobbies on behalf of a variety of issues, including age discrimination and flexible retirement ages. On pension issues, ARP/O50 has endorsed positions such as a lower contributions history threshold for receiving a full Basic State Pension and gender equalization of the retirement age at 60 - neither of which are likely to be adopted by either a Conservative or a Labour government because of their fiscal implications. Its membership is generally younger and more affluent than other pensioners' organizations, and its resources more devoted to membership services such as low-cost travel opportunities and holiday insurance. ${ }^{19}$

\section{PENSION POLICYMAKING SINCE 1980}

Margaret Thatcher's Conservative government came to power in 1979 with a strong determination both to reduce state expenditures and to roll back the role of the state more generally. As noted above, the Thatcher government's initial move, in 1980, was to change the standard for indexing the basic state pension, from the higher of wages and prices to simply prices. This allowed the government to claim, correctly, that they were preserving the real purchasing power of benefits while cutting the role of the Basic Pension substantially over time.

19 Jay Ginn and Sara Arber, "The Politics of Old Age in the UK," pp. 152-167 in Alan Walker and Gerhard Naegele, eds., The Politics of Old Age in Europe, Buckingham and Philadelphia: Open University Press, 1999, at pp. 161-162. 


\section{The Social Security Review and Personal Pensions}

The State Earnings Related Pension Scheme was a modest expenditure drain in the early Thatcher years — as late as the 1984/85 fiscal year, it comprised less than one percent of expenditures on cash benefits to those of pension age. ${ }^{20}$ However, SERPS was likely to be a growing drain on expenditures as it matured. In the run-up to the 1983 general election, Mrs. Thatcher denied any intention of touching SERPS. ${ }^{21}$ But after the Conservatives' sweeping victory in that election-397 of 650 House of Commons seats, compared to only 209 for Labour-Treasury pushed very hard for major cuts in social spending, and both Treasury and the Prime Minister warned that pensions were the major long-term threat to public expenditures. ${ }^{22}$ Between 1983 and 1985, Norman Fowler, the Secretary of State for Social Services, carried out a series of reviews of Britain's main income transfer programs, including SERPS. ${ }^{23}$ The resulting government discussion document (or "Green Paper"), Reform of Social Security, harshly criticized SERPS as likely to squeeze out any other form of increased social spending (notably on health) once it was fully mature after the turn of the century. ${ }^{24}$ Existing occupational pensions, too, came in for criticism as inhibiting labor mobility.

\footnotetext{
${ }^{20}$ Expenditures on basic pensions were around 83 percent, Supplementary (means-tested) Benefits about five percent, and Housing Benefit about 12 percent. Secretary of State for Social Services, Reform of Social Security, London: Her Majesty's Stationery Office, Cmnd 9517, vol 2, p. 3

${ }^{21}$ See Pierson, Dismantling the Welfare State?, p. 60, Levin, Making Social Policy, pp. 144-147.

${ }^{22}$ Pierson, Dismantling the Welfare State?, p. 60.

${ }^{23}$ See the discussion in Peter Levin, Making Social Policy, Buckingham and Philadelphia: Open University Press, 1997, chapter 7. For first hand accounts by participants, see Lawson and Fowler.

24 The Green Paper also sought to counter the argument that SERPS provided a needed degree of certainty in pensions after prolonged debate by arguing that the Labour Party's proposal for investing pension funds into a National Investment Bank would upset that
} 
The Green Paper proposed a radical solution for SERPS: rather than simply reducing benefits, the program was to be phased out over a three year period for men under age 50 and women under age 45 (older workers would remain in the current system). Current entitlements earned under SERPS would be honored (with enhanced credits for those in a transitional ten-year age cohort), but younger workers were expected to enter either into occupational pensions or new "personal pensions" that were expected to be offered by insurance companies, building and friendly societies and other providers. Occupational pensions were to be encouraged by allowing employers to offer "money purchase" (funded defined contribution) pensions rather than "the open-ended promise of a defined benefit scheme. ${ }^{25}$ Some hot issues, like raising the retirement age (or equalizing it for men and women) were dodged in the Green Paper. Others questions, such as whether annuity providers would be expected to provide pensions on a genderneutral basis (contrary to then-existing practice) in the new system were left open for future discussion.

Not surprisingly, the Green Paper proposals proved to be highly controversial, and the pension provisions especially so. Powerful interests, including the Confederation of British Industry, the National Association of Pension Funds, and major insurance companies, criticized abolition of SERPS. ${ }^{26}$ In addition, the government was itself

stability in any case if they ever came back into power. See Fowler, Reform of Social Security, vol. 1, p.22-23.

${ }^{25}$ Secretary of State for Social Services, Reform of Social Security, London: Her Majesty's Stationery Office, Cmnd 9517, vol 2, p. 6. Flexibility was also to be offered in contributions rates (although there was to be a minimum rate of 4 percent after a transitional period.

${ }^{26}$ See Secretary of State for Social Services, Reform of Social Security:Programme for Action, London: Her Majesty's Stationery Office, Cmnd 9691, December 1985, p. 12. See also Secretary of State for Social Services, Social Security Bill 1986:Report by the 
divided: while Prime Minister Thatcher favored abolition of SERPS, for example, the Chancellor of the Exchequer, Nigel Lawson, was opposed because of the short-term fiscal impact of the transition.

The final version of the reforms, enacted as the Social Security Act, 1986, did not abolish SERPS, but it cut back dramatically on its benefits, generally in ways that preserved existing entitlements and pushed the most visible cuts fairly far into the future. Rather than replacing a maximum of 25 percent of earnings, future SERPS accruals were lowered so that only 20 percent of earnings would be replaced for future earnings, beginning in 1988. Moreover, those pension benefits would be based on lifetime earnings (from age 16 to retirement age) rather than the best twenty years, with protections included for years spent out of the labor force as caregivers. Perhaps the most visible cut was a reduction of the SERPs benefit received by surviving spouses of retired workers from the entire benefit to only one-half; but this would not occur until $2002 .{ }^{27}$ Overall, the cuts were expected to cut SERPS payments through the year 2035 roughly in half.

For occupational pension funds, there was mixed news. On the one hand, they only had to meet the new, lower twenty percent standards for pension benefits. Employers were also offered the opportunity to offer their pensions on a defined contribution rather than defined benefit basis. But under the new law they, rather than the state, would be responsible for the first three percent of price inflation for pensions once they began to be paid. Workers who changed jobs after less than five years also

Government Actuary on the Financial Effects of the Bill on the National Insurance Fund, London: Her Majesty's Stationery Office, Cmnd 9711,January 1986.

${ }^{27}$ Contracted-out pensions would also have to pay a pension to surviving spouses of retirees 
gained additional rights to preserve or transfer their pension rights, addressing the perceived negative consequences of occupational pensions for labor mobility.

The most dramatic innovation, though was the introduction of "personal pensions" on a defined contribution basis available to everyone - those whose employers offered occupational pensions as well as those who did not.

\section{Reforms Under Major}

Further pension reforms under John Major, who succeeded Margaret Thatcher as prime minister after a cabinet rebellion in 1992, largely continued the direction of reforms under Thatcher. The 1995 Pension Act set in place a prolonged timetable for equalization of the standard retirement age. It also made further savings in SERPS.

In the leadup to the 1997 general election, which it was expected to lose by a landslide, the Major government, desperate to come up with a bold idea that could turn around its failing fortunes, proposed a change even more dramatic than those proposed by Margaret Thatcher: the phasing out of both the Basic State Pension and SERPS and their replacement with a system of compulsory private pensions financed by rebates from National Insurance contributions. The state would guarantee a minimum payment equal to the existing Basic State pension upgraded for inflation — and thus presumably declining over time relative to average wages. ${ }^{28}$ The proposal would be phased in over

\footnotetext{
${ }^{28}$ For a brief description, see Anne Ashworth and Caroline Merrell, "Looking for a Bright Idea to Meet the Challenges of a Grey Future," The Times London), April 26, 1997. The plan would have been paid for in part by moving from a system in which pension contributions were tax exempt and pension income taxed to a system of taxable contributions and tax-free pensions up to some limit. Changing taxation of pension contributions was criticized by the National Association of Pension Funds, which argued that it could lead to the demise of occupational pension funds if employees became liable for taxes paid by employers on their behalf as well any additional voluntary contributions they made themselves to such funds. Jon Hibbs, "Company Pension Schemes 'At Risk' Under Lilley Plan,"” Daily Telegraph, March 14, 1997, p. 12.
} 
40 years, and would result in higher expenditures in the short and medium term (to pay pensions for current and near-term retirees, making up for pensions no longer being paid into National Insurance funds), but result in massive expenditure savings in the long term, while transferring most of the risk of an uncertain upside and downside investment to future pensioners.

\section{Policymaking in the Blair Government}

The "New Labour" Party headed by Tony Blair won a stunning victory in the May 1997 general election: 419 seats in House of Commons for a majority of $179 .^{29}$ But the new government also confronted an important set of constraints, both external and self-imposed, in pension policy. First, Labour had promised during the election campaign to hold its expenditure levels to those promised by the Major government for its first three years. Thus any increased expenditures in some areas of social spending would have to be met by reductions in other areas. Moreover, Labour had promised not to increase taxes, and had promised to focus expenditure increases on education, health and employment initiatives. ${ }^{30}$ As a result, there was limited political commitment, and even less money, available to make new spending commitments for pensions.

Although Labour had severely criticized the Conservative Party's pledge to phase out SERPS in favor of a privatized plan during the general election campaign, there were some within the Labour Party, notably Frank Field, a leading intellectual force and

\footnotetext{
${ }^{29}$ On the Labour victory and its aftermath, see for example Ivor Crewe, "Elections and Public Opinion," pp. 67-94 in Anthony Seddon, The Blair Effect: The Blair Government,1997-2001, London: Little Brown, 2001,and Anthony Geddes and Jonathan Tonge, eds., Labour's Landslide, Manchester: Manchester University Press, 1997.

${ }^{30}$ See for example Andrew Rawnsley, Servants of the People: The Inside Story of New Labour, London: Hamish Hamilton, 2000, p. 5.
} 
former head of the Child Poverty Action Group, who believed that Labour ought to move in the direction of compulsory private savings for the many combined with a state pickup of the costs for the less well-off. ${ }^{31}$ Blair appointed Field as minister responsible for welfare reform with a mandate to "think the unthinkable," but he did not give him responsibility over the Department of Social Security (that post went to Harriett Harman) or open pursestrings. Harman and Field worked poorly together, and both lost their posts in the Blair government's first cabinet reshuffle. Pensions policy increasingly was driven by the desire of Chancellor of the Exchequer (Treasury Minister) Gordon Brown and the Treasury to keep pensions costs down by concentrating increased expenditures down by use of means-tested benefits rather than increasing the Basic State Pension.

In December 1998 the Blair government revealed its own proposals for pension reform. There were three main components. First, the Government would establish a Minimum Income Guarantee for pensioners higher than both the level of means-tested Income Support available to pensioners and the Basic State Pension. Pensioners already enjoyed a higher means-tested Income Support level than other Britons, but the "rebadging" as a Minimum Income Guarantee was intended to address problems of lowtake-up among seniors who did not want to accept means-tested benefits. was more innovative was that the government proclaimed that the new Minimum Income Guarantee was in principle (although not in statute) to be upgraded annually for increases in average earnings rather than prices; thus low-income pensioners would share in the growth of the overall economy.

${ }^{31}$ Indeed, Field had publicly praised the Conservative plan when it was released. See Fran Abrams, "Labour splits Over Serps Scheme," The Independent (London), March 6, 1997, p. 8; Patrick Hennessy, "Opposition Split as Kewy MP Praises Tory Pension Plans," Evening Standard (London) March 6, 1997, p. 6. For Field's views, see The State of Dependency: Welfare Under Labour, London: Social Market Foundation, 2000. 
Second, SERPS was to be phased out (although accrued benefit entitlements would remain in place) and replaced with a new State Second Pension (S2P), targeted on low-earners. It would provide higher benefits for low-wage earners: those who made above the Lower Earnings Level at which National Insurance contributions start to be made would be credited with earnings of $£ 9,000$ for purposes of the S2P. Moreover, qualifying caregivers (those caring for children under age 6 and for invalids) and persons who had inconsistent labor market participation as a result of disability would also be credited with S2P contributions. Persons who contracted out of the S2P would receive contribution rebates and top-ups intended to make them no worse off than if they had stayed in the state system. The most dramatic change from SERPS, however, was that a few years after its introduction, S2P benefit accruals were to become flat-rate rather than earnings-related: this was intended to provide a strong incentive for workers earning significantly more than $£ 9,500$ per year to contract out of the S2P. Overall, the State Second Pension was expected to provide substantially higher benefits to low-income workers when they retired. The Department of Social Security estimated that the percentage of retirees qualifying for the Minimum Income Guarantee would be lowered from one in three to one in five by the S2P. Net costs to the Treasury (taking account of lower means-tested benefits payable) were estimated at $£ 0.3$ billion in 2010 , rising to $£ 4.4$ billion by $2050 .{ }^{32}$

The third component of the government's proposals was labeled "stakeholder pensions." It was intended to deal with the problems of high (and frequently frontloaded and/or obscure) charges on personal pensions that made them a poor retirement savings

32 Department of Social Security, Fact Sheets on Social Security: Second State Pension, http://www.dss.gov.uk/publications/dss/2000/fsheets/s2p.htm, accessed September 19, 2000. 
vehicle for persons of modest earnings, and made moving savings from one fund to another even more problematic. ${ }^{33}$ Like personal pensions (and unlike SERPS and S2P), stakeholder pensions were to be defined contribution rather than defined benefit schemes provided by the private sector. But management fees were to be more heavily regulated: they were to be set as a percentage of the value of a person's total assets in the fund, and could not exceed one percent of those assets per annum. To encourage low-earners to contribute, stakeholder funds were required to accept contributions as low as $£ 10$, and could not penalize fund members for failing to make minimum (or making no contributions) for some period. Moreover, fund members could transfer their stakeholder pension to another fund without charge. Most employers, including small employers, would be required to designate a stakeholder fund to which employees could make contributions. Contributions of up to $£ 3,600$ per year could be made to stakeholders on a person's behalf regardless of their earnings. Earnings on stakeholder pensions were to be tax-free; taxes were to be paid at normal rates on withdrawals, except for a lump sum up to a maximum of 25 percent the value of the fund at the time of retirement. All of these provisions were designed to make stakeholders more appropriate for lower income workers, while creating a product image that was more positive than that associated with personal pensions, which had been severely damaged by the misselling scandal of the late 1980s.

While the Blair government's reforms did indeed increase incomes for the poorest pensioners, many in the party felt that they did not go far enough. In particular, increases in the Minimum Income Guarantee, and a pledge that it would be uprated with earnings,

\footnotetext{
33 On Stakeholder pensions, see Richard Disney, Carl Emerson and Sarah Tanner, and Emmerson and Tanner,
} 
meant that the Basic State Pension was increasingly irrelevant for many pensioners with the lowest incomes. But the politics of pensions received a major jolt in 2000, when the Blair government announced its price-related adjustment of the Basic Pension for the following year: a paltry 75 pence. Rather than being seen as a triumph of inflationcontrol policies, it was instead seen as a slap in the face at pensioners. And there was more: in March the government admitted that a change made as part of the Thatcher government's 1986 reforms, which would give widows only half of their spouse's benefits under SERPS beginning in April 2000, had not been publicized by DSS; indeed the Department had continued to publish incorrect information that led widows to think that they would continue to inherit their husband's entire SERPS benefit. Once again, the government's initial (cost-saving) reaction was far from sure-footed, promising only to delay the change for 30 months, and to provide compensation to widows who could show that they were "actively misled" by government officials rather than simply ignorant of it. $^{34}$

By late 2002, the Blair government was claiming that its reforms had made the average pensioner household " $£ 1,150$ a year better off in real terms, compared with 1997," with those gains concentrated among lower income pensioners, and that there had been significant reductions in senior poverty under New Labour. ${ }^{35}$ In the press, however, there was increasing talk of a U.K. "pensions crisis," with several elements. One of the most alarming trends was an increasing tendency for employers operating defined benefit pension plans to close those plans to new employees, and sometimes to existing

${ }^{34}$ Paul Eastham, “ The Astonishing Cost of Sorting Out Whitehall Pensions Mix-up," Daily Mail (London), August 17, 2000, p. 13; Andrew Sparrow, "Darling Refuses to Raise SERPS Payout," Daily Telegraph (London), August 18, 2000, p. 10.

${ }^{35}$ Department for Work and Pensions, Her Majesty's Treasury, and Inland Revenue, Simplicity, Security and Choice, pp. v,22. 
employees as well. These plans were replaced with defined contribution pensions, usually with a substantial cut in employer contributions. These plan closures were at least in part a result of the Blair government's decision to introduce an insurance scheme for employer plans, which will increase the costs of such plans to employers.

The new stakeholder pension has also largely failed to achieve its objective of providing a cheap accessible retirement savings product for women and low-income families. Overall levels of stakeholder sales have been disappointing, and most of those sold have in fact been purchased by higher income families, who are more likely to be able to afford them and who are more likely to be targeted in marketing by the firms providing them. ${ }^{36}$ These disappointing sales figures may also reflect conflicting advice presented in the media by industry experts about whether it makes sense for low-earners to save in pensions or more flexible savings tax-advantaged savings instruments. ${ }^{37}$

Another important set of questions concerns incentives for private retirement savings. The expansion of means-tested programs under the Blair government through the Minimum Income Guarantee enrichment and a new Pension Credit has substantially increased the number of Britons who face substantial savings disincentives because benefits are withdrawn as income from retirement savings increases. The Pension Credit was designed to address this problem but does so only in part (Pension Credit recipients

\footnotetext{
${ }^{36}$ See Bill Jamieson, "Moving Out of the Pensions Morass," The Scotsman, December 15, 2002, p. 9

${ }^{37}$ The argument against saving in stakeholders is that (1) other savings vehicles, notably ISAs provide greater flexibility on withdrawals and don't have annual fees, (2) lowearners are unlikely to be able to take full advantage of the tax advantages on deposits to stakeholder accounts, and (3) they are unlikely to have a retirement income above the minimum income guarantee, and thus will be subject to high tax rates on any retirement savings they do accrue. For a good example of conflicting arguments by pension experts in the media, see Tony Hazell, "Pensions Chaos Too Confusing," Daily Mail, March 19, 2003 , p. 54.
} 
lose 60 pence for every pound of retirement income rather than 100 under the prior system). ${ }^{38}$ The percentage of pensioners receiving means-tested benefits has been projected by the Institute for Fiscal Studies to rise from 37 percent in 1997 to 58 percent in 2003 with the introduction of the Pension Credit and up to 73 percent by 2025 and 82 percent by $2050 .{ }^{39}$

Concerns have also been raised about whether the Pension Credit will in fact reach those for whom it is intended, given the complex application procedures for the new benefit and the widespread administrative snafus that accompanied the government's introduction of a Working Families Tax Credit in 2003.

Further uncertainty and confusion was sewn among holders of private pension accounts in the United Kingdom in the spring of 2003 when several large financial services companies announced that, in the absence of explicit instructions to the contrary, they planned to contract personal pension policyholders back into the State Second Pension. Uncertain financial markets and falling annuity yields made that the most prudent course of action for most investors, they argued, not just older and lower-income workers. ${ }^{40}$ Nervousness has also increased among workers in occupational plans, who saw the pension promises made to future retirees of pension funds operated by failed firms being slashed because courts ruled that guarantees made by those plans to current

\footnotetext{
${ }^{38}$ For criticisms of the Pension Credit, see for example Nicholas Timmins, "Call for Changes to State Pension System," Financial Times, March 17, 2003, p. 8.

${ }^{39}$ Tony Tassell, "Tories Want All Employees in Company Plans," Financial Times, May 24, 2003 p. 4.

${ }^{40}$ See for example Clare Francis and Adam Jaques, "In? Out? The People Who Left SERPS Are Shaken All About," Independent on Sunday, March 9, 2003, p. 12, Clare Francis, "Savers Told to Opt Back Into State Pension System," Sunday Times, June 22, 2003, Money section, p. 4, Helen Pridham, "Should I stay Out or Should I Contract Back In?," The Times, June 28, 2003, Money section, p. 7.
} 
retirees must be honored in full, while those who have not yet retired enjoy a much lower degree of protection.

There are other threats on the horizon as well. At least one U.K. life insurance company has announced that it may in the future move to a system of awarding differential annuities based on the residential postal code of new annuitants, in recognition of the fact that residents in wealthy areas are likely, on average, to live longer than those in poorer areas. ${ }^{41}$ This policy cannot be applied to the part of an individual's "pension pot" that is financed through rebates from National Insurance contributions. And it remains to be seen whether it will be actually implemented - and if it is implemented, whether those in wealthier postal codes will develop successful strategies to evade it. But it adds further to an already widespread feeling of unease about the pension system.

During its second term, the Blair government proposed several further reforms to address these shortcomings in pension policy. In December 2002, the government issued yet another pensions Green Paper that proposed scrapping the confusing current array of eight different schemes for tax-advantaged retirement savings and replacing them with a single lifetime limit for tax-advantaged pension savings accruals. The Green paper also proposed greater retirement age flexibility, but no changes to the fundamental publicprivate pensions mix in the U.K or an increase in the retirement age above $65 .{ }^{42}$ Another Green paper in June 2003 focused on the crisis in defined-benefit occupational pensions.

${ }^{41}$ Richard Palmer, "Pensions Blow to Middle Classes," Daily Express, July 7, 2003, p. 1 ${ }^{42}$ See Department for Work and Pensions, Her Majesty's Treasury, and Inland Revenue, Simplicity, Security and Choice. For a sampling of industry and interest group reactions to the government's proposals, see for example Graeme Wilson and Dareen Behar, "Save More or Work Beyond Age of 65," Daily Mail, December 18, 2002, p. 1; Anthony Harrington, "Modest Green Paper Proposals Gain Mild Instustry Approval," The Scotsman, December 19, 2002, p. 25. 
It proposed a pension insurance fund for underfunded schemes of insolvent employers, modeled after the Pension Benefit Guaranty Corporation in the United States, and funded by employer contributions. The Green Paper also proposed measures to make it harder for solvent employers to avoid their pension obligations by closing down their DB pension schemes, lessened the requirements of such schemes to provide inflation protection for retirees, and proposed a new, more pro-active regulator for such funds. ${ }^{43}$

A variety of other proposals have emerged from pension providers and other stakeholders, notably proposals to fold the new State Second Pension into a higher Basic State Pension. ${ }^{44}$ But such proposals are not greeted enthusiastically in the Treasury, which views means-testing as a way to target and thus hold down expenditures. ${ }^{45}$ Nothing close to a consensus has emerged, and perceptions of a pensions crisis remain widespread.

\section{REFLECTIONS ON THE U.K. CASE}

\section{Patterns}

${ }^{43}$ Department for Work and Pensions, Her Majesty's Treasury, and Inland Revenue, Simplicity, Security and Choice: Working and Saving for Retirement-Action on Occupational Pensions, London: Her Majesty's Stationery Office, Cm 5835, June 2003. ${ }^{44}$ The National Association of Pension Funds favors scrapping the State Second Pension and replacing it with a higher basic pension, paid for by gradually raising the retirement age to 70 and an end to contracting out. NAPF would also scrap the Minimum Income Guarantee and Pension Credit and increasing tax incentives for retirement savings. See National Association of Pension Funds, Pensions-Plain and Simple, London: NAPF, October 2002. See also Rupert Jones, Funds Push Universal Citizen's Pension, The Guardian, October 8, 2002, p. 24. The Association of British Insurers, on the other hand, has also called for a higher flat-rate S2P for low-earners, but also an expansion of rebates for middle and upper earners. Like the NAPF proposals, it was intended to reduce reliance on means-testing and thus savings disincentives. See Allison Steed, "ABI Weighs Into State Pensions," Daily Telegraph, March 17, 2003, p. 36. The TUC favors a continuation of contracting out, but mandatory employer pension contributions.

${ }^{45}$ See for example Larry Elliott, "Hero or Villain? Brown Faces a Means Testing Time in Dilemma Over Pensions, The Guardian, October 2, 2000, p. 23. 
Two major features stand out about the nature of policy change in the U.K. First, the degree of reform has been stunning. Second, reform has been frequent, with major pension reforms in 1980, 1986, 1996, and 2000.

There also several striking patterns in outcomes. First, the U.K systems is extraordinarily complex - and confusing. Second, the public component of the pension system — and especially its income-related component— has been increasingly marginalized, a pattern that began under Margaret Thatcher and has continued under Tony Blair. But there has also been an increased reliance on means-tested pensions under Blair.

\section{Explanations}

Britain has made by far the most dramatic pension policy changes of all the countries considered here over the past two decades, moving to a system in which private pensions have been given an enhanced role, and public pensions have been marginalized and repeatedly altered, although not abolished. How can this pattern be explained? Clearly it cannot be solely explained by either demographic or fiscal crisis. Britain has one of the lowest current and projected public pension liabilities among the OECD countries. Three major features stand out as key in explaining these outcomes: policy inheritances or "path dependence" from prior policy choices, a Westminster-style parliamentary system that concentrated power to the governing party, and a party system that in the late 1970s and early 1980s gave the governing Conservative Party limited fear of electoral retribution as it enacted a series of controversial policies.

It is very doubtful that policy changes - and benefit cuts under Thatcher--of the magnitude of those seen in the U.K. could have been enacted without Britain's 
Westminster style parliamentary institutions, which give governments with a plurality of the vote parliamentary majorities, and those elected with a near-majority of the vote huge majorities of parliamentary seats. Westminster institutions alone are not an adequate explanation of this phenomenon, however. In New Zealand, bold retrenchment after elections was usually preceded by competition for elderly votes during election periods and followed by policy reversals prior to the next election. In Canada, the Mulroney government was cautious in enacting pension retrenchment even after its sweeping Parliamentary victory in 1984, and never attempted anything as bold as the reforms that have occurred in the U.K.

In both Canada and New Zealand, party competition was much closer than it has been in the U.K. In elections since 1980, only the 1992 election - a surprise victory for the Conservatives under John Major —was relatively close. Margaret Thatcher's victories in the 1980s were routs, in part because the Labour Party was torn by internal conflicts and perceived as far from the positions of median voters. Labour's victories in 1997 and 2001 were even more devastating. And despite a much reduced Labour majority in the 2005 election, the Conservatives remained very weak and divided. Thus in none of these elections were appeals for senior votes seen as keys to an electoral victory that otherwise might slip away. And in both 1992 and 1997, Labour was reluctant to make pledges that could be seen as fiscally irresponsible for fear that it would bring back visions of "Old Labour" that Margaret Thatcher (with the help of the Labour left) had so successfully demonized. In short, Westminster institutions created an institutional opportunity for policy restructuring by giving the Thatcher government the capacity to enact such change, but the lack of effective political competition was also 
critical by (1) allowing a government to take office which was far from the preferences of median voters, and (2) giving the Thatcher government the political will to enact major changes without major concern over the political consequences.

When a chastened Labour Party returned to power after eighteen years in 1997, they were compelled to operate within a policy and political world that was very much of the Conservatives' making. Personal pensions were well-established, and popular with both providers and a (mostly middle and upper income) section on the populace that liked and used them. Equally important, Labour was trapped within a Thatcherite set of policies on taxes that made greater extension of universalistic or earnings-related pension programs implausible. New Labour was not disposed to move in that direction in any case - their emphasis was on cooperation with the private sector wherever possible. But the contours of what was possible and how Labour reacted to emerging tensions and crises were in the British pension system were shaped by the Thatcherite experience.

The dominant policymaking role played by Treasury and its single-minded emphasis on expenditure reduction, is another important forces contributing to the success of retrenchment and restructuring initiatives in the U.K. Indeed Frank Field, at the end of his ill-fated sojourn as Minister for Social Reform is reported to have told Prime Minister Blair that the Department of Social Security might just as well be folded into the Treasury. ${ }^{46}$

\section{Challenges and Choices}

Developing a report card for the British pension system is an exercise in extremes.

On some measures, it stands out as superior to most or all in the club of rich OECD countries. In other respects, it can only be regarded as a dismal failure, reflecting trade-

${ }^{46}$ Rawnsley, Servants of the People, p. 120 
offs inherent in a set of choices that is both unusual and extreme the role given to private pension providers.

In terms of pension adequacy — provision of a minimum floor that is broadly available and effective in alleviating poverty, particularly with respect to vulnerable groups such as widows and those who spent long times in unpaid caregiving, the British system until recently had a poor record, with high rates of relative and absolute poverty. Here the Blair reforms to means-tested pensions have in fact made an important difference for low-income pensioners, although low-rates of take-up, especially among lowest-income pensioners and minorities mean that it still has a mediocre record. The broader accessibility and higher benefits under the new State Second Pension should gradually improve pension adequacy, at least for those with low-earners with fairly complete earnings histories.

Perhaps the greatest shortcoming of the British pension system is with respect to clarity: ease of comprehension, low and unskewed information costs, clear and consistent signals about the advantages and disadvantages of retiring at various ages, consistent rules that allow for effective retirement planning, etc. The U.K. system is the antithesis of clarity, with frequent changes in rules, extreme complexity, and the likelihood that many workers will accrue multiple pension rights of several different types. In its 2002 Green paper, the Blair government called for pension fund managers to issue clear statements of how much future retirees will likely receive in the future. But a consolidated statement that brings together all likely sources of pension income in a consolidated statement remains far in the future. And most importantly, the almost 
constant ferment of government policy change makes responsible planning by individuals and even pension providers difficult.

In addition, the U.K pension system earns very poor marks for riskiness. Indeed, what is remarkable about the U.K. pension system is the range of risks to which British pensioners have been exposed. Together the high degree of privatization in the British pension system and the volatility of pension policy have given rise not only to familiar financial market risks (risks that pensions will be affected by falling financial markets), but also employer-specific risks (that an employer will go bankrupt, leaving behind an under-funded pension fund), annuitization risks (shifts in annuity prices over time), and political risks (risks that government will renege on explicit or implicit promises it has made to present and future pensioners). Finally, as noted above, U.K. pensioners may also in the future face what might be called "financial industry practice risks"-risks that changing financial industry practices such as annuity prices varying by postal codes might result in a different pension than anticipated after an individual has already made a long term commitment to build a pension through a defined contribution pension rather than remaining in the state defined benefit system. These risks are felt to different degrees by employees who make different choices about where to entrust their provision for retirement. Moreover, several of the risks have been poorly conveyed to workers. This is particularly true of the risk of pension losses caused by firm insolvency leaving behind an underfunded pension fund. As British pension expert Ros Altman has noted, "workers have been hoodwinked into thinking the best thing they could do was contribute 
loyally and regularly to their employer's pension scheme... [without] any warning they could lose the lot." ${ }^{, 47}$

The pension system in the United Kingdom also earns low marks for administrative effectiveness and efficiency. Britain's high-cost retail method of marketing personal pensions and annuities, the extension of recurrent means-testing to a majority of seniors through the Pension Credit, and the low take-up rates for means-tested benefits, especially among the most disadvantaged seniors are all indicators of a pension system that has serious problems in meeting its objectives.

Despite the recent spate of changes under the Blair government, many critical challenges remain. A central challenge for British pension policy as it faces the future is to create a sensible, intelligible set of investment choices for individuals. The current array of pension products is so confusing that most contributors cannot understand the choice of options that is confronting them, let alone make the most appropriate choice among those options. A second central challenge for the U.K. is how to develop a pension system that provides an adequate pension to low-wage earners and those (disproportionately women) who have spent little time in the paid labor force without removing savings incentives.

\section{Lessons for the United States}

The U.K. experience shows that designing and implementing a partial opt-out from a public pension system is an extremely complex task. How should pension fund

\footnotetext{
${ }^{47}$ quoted in Jeff Prestridge, "Our Three Wishes... and How They Could Tackle Britain's Pension Crisis," Mail on Sunday, December 15, 2002, p. 13. For example, the Pensions Service, which administers Britain's public pension system, advises that "if your employer runs an occupational scheme, it will normally be a better vdeal for you than any pension you take out yourself." Pension Service, Personal Pensions-Your Guide, Pension Service, October 2002, p. 7.
} 
contributions and withdrawals be processed? Should all pension fund contributions and earnings be annuitized at retirement, or should lump-sum withdrawals be allowed, and if so, how much? How complex should the range of products offered be? Who should be allowed to offer pension products, and how should pension funds be regulated? The U.K experience offers a number of potential lessons for U.S. policymakers about the pitfalls that are likely to arise in such a system.

Some lessons that emerge from U.K. experience appear to have been absorbed by the Bush administration in its tentative spring 2005 plans for creating individual account options within Social Security, notably British experiences with respect to the number of investment options offered and the problems of private-provider annuitization. There is no guarantee, however, that the Bush administration's proposals will serve as the blueprint for legislation that emerge in the future from Congress: in the complex policymaking system of the United States, with very limited agenda control by the executive, lessons that have been learned by one set of policymakers may not be learned by others who have the power to amend executive proposals. And the desire to reach a deal may allow the inclusion of provisions in legislation that many participants know to be bad ideas. It is therefore worth including here some lessons that have already been learned by the Bush administration but are by no means guaranteed to guide any Social Security reform package that might emerge from Congress in the future.

First, the U.K. experience suggests that complex interactions between public and opt-out pensions create confusion among workers, leading to both discontent and demands for policy change. This is particularly evident in the British case, and stems from the differing ways that entitlement to benefits is earned in defined benefit and 
defined contribution systems. Contributions made to a defined contribution tier earlier in one's working life are likely to garner a higher eventual annuitized pension value than those made shortly before retirement, because they have a longer time to accrue capital gains, dividends or interest. Contributions to a defined benefit plan, on the other hand, are generally indexed for wage growth, so that returns on contributions of equal real value are likely to provide relatively equal returns whether made early or late in a worker's career. Thus it is likely that many workers would find it advantageous to opt back in to a state defined benefit plan at some point if they are allowed to do so. For most workers, however, it is unclear where that point is.

It is possible to address this problem, as in the U.K., by increasing the National Insurance rebate for older workers, gives them greater incentives to opt out, but makes the system more complicated, and more opaque. Moreover, it makes much less sense to offer age-related rebates in the U.S. system, where there is a closer linkage between contribution rates and benefits, and where the absence of general revenue financing means that more generous Social Security contribution rebates would undermine the financing of the entire Social Security program. The leading alternative in the U.S.reductions in Social Security benefits for personal account holders that would be neutral in effect if return on account balances equaled inflation plus three percent-is almost certain to generate confusion among the vast majority of account holders who do not have a Ph.D. in economics.

A second and related lesson suggested by British experience is that a pension system that allows recurrent opt-ins and opt-outs from the state system may lead both to increased complexity for administrators and pension savers and to potential legitimacy 
problems for the entire system. A different alternative, requiring young workers to make a one-time irrevocable choice to opt-out or opt-in from OASI, that they would have to live with for forty years or more, is probably not appropriate, and almost certainly not politically sustainable in the U.S. context. Even if workers who had opted out were provided an investment option that essentially allowed them to guard against further perceived losses while staying in the individual account system, it is unlikely that this alternative would be politically sufficient.

A third lesson is that the market may not, unprompted, provide personal pension vehicles that are appropriate retirement savings vehicles for low-earners, especially those who have interrupted earnings records. The problem of making appropriate choices in opting out of a state pension system is likely to be particularly acute in the United States, given the very high returns on contributions of low-wage workers under Social Security. Workers who are encouraged to opt-out inappropriately by government could cause an even greater political uproar than the pension mis-selling scandal in the United Kingdom.

A fourth lesson is that price indexation of wage histories is likely to create pressures for ad hoc policy change. This is particularly true if, as has been suggested, price indexing would involve a stable purchasing power for benefits over time relative to the wage of average workers. This flat real benefit would be "earned" by earnings that are increasing in real terms over time-in other words, it would comprise a very large decrease in Social Security replacement rates. ${ }^{48}$ In the U.K., a huge decline in the purchasing power of the Basic State Pension relative to average wages has in the Blair years been addressed primarily by the expansion of means-tested benefits combined with

${ }^{48}$ Alicia H. Munnell and Mauricio Soto, What Does Price Indexing Mean for Social Security Benefits?, Chestnut Hill, MA.: Center for Retirement Research at Boston College Just The Facts on Retirement Issues Number 14, January 2005. 
an expansion of credits for retirement savings. But it is far from clear that this will be politically sustainable; as noted above, this strategy has come under widespread criticism and may not be politically sustainable much longer. The political risk of such a proposal is that it would open up a Social Security system that has been almost immune from changes over the past twenty years to a renewal of the bidding wars that characterized Social Security policymaking in the 1960s and early 1970s.

Fifth, increased reliance on means-tested pensions increases administrative complexity and creates perverse incentives for savings and for types of assets held, especially where assets as well as income-tests are involved. While increased reliance on means-testing is not part of most of the proposals currently being discussed in the United States, the discussion above suggests that it could arise over time if replacement rates for Social Security fell as part of a Social Security reform package.

Sixth, providing an opportunity for a partial opt-out into individual investment accounts is likely to lead to pressures to treat those pensions more like fully private pensions with respect to flexibility in withdrawals, inheritability, and ability to borrow against fund balances. In the case of current proposals being circulated in the United States, the biggest issues are likely to arise with respect to inheritability of benefits. If individual account balances were to be partially offset at retirement by amounts that reflect Social Security benefits foregone, for example, inheritable balances would be far lower than account holders and their survivors expect. Early retirees would likely demand that they have access to Social Security individual account balances at the same times as IRAs. The devil will be in the details of interaction of Social Security benefits and individual account balances and in the way that account balances are presented to 
account holders. But it will also be in a new political dynamic created by individual accounts - and in the desire of legislators to be responsive to the new demands that an individual account system would prompt in recipients.

Seventh, annuitization costs can add significantly to pension system costs and inequality across cohorts, so the state may want to take on the role of monopoly annuity provider. Again, this lesson appears to have been absorbed in early proposals from the Bush administration. British experience suggests that it is important to retain this element of current proposals as debates on Social Security reform continue.

An eighth lesson from the British experience is that scandals and policy failures help to drive policymaking. Politicians respond to scandals - although not always in the most appropriate ways - because the public expects them to bring the perpetrators of unacceptable actions to account, to mitigate the consequences of such actions, and to prevent a repeat of those actions. The Major and Blair governments have had to respond to three major scandals: the pension mis-selling scandal of the late 1980s, the Maxwell occupational pensions scandal, and the failure of DSS to publicize changed policies on widows' inheritance of SERPS benefits. There is little doubt that given the incentives of credit-claiming and blame-avoiding politicians in the decentralized policymaking process in the United States, scandal-driven policymaking would be at least as important in the United States. Thus it is important to get the policy design right the first time, to take substantial time to get implementation mechanisms in place, and to invest heavily in public understanding of how the reform will work to lessen the possibility that public misunderstandings will lead to backlash and tireless tinkering with policy—which in turn would risk further public misunderstandings. 
A final lesson is that scandals, policy tinkering, and uncertainty over pension policy may affect workers' propensity to opt out of state pensions in unpredictable ways. We might expect that uncertainty over state pension policy—especially when it involves tinkering in which the overall trend is toward retrenchment--would lead to a loss of confidence in and exit from the state system when exit is allowed as an option. A key perceived advantage of a state pension is that it is secure rather than risky. If workers are (1) confused about the relative advantages of public and private options by repeated changes in the public system, and/or (2) no more sure about the fate that their pension is likely to suffer at the hands of future politicians than they are about the returns on investments in the markets, they are presumably more likely to opt for individual account options when they are given a choice. But the U.K. experience does not provide strong evidence for this view. Indeed, the overall trend between 1991/2 and 2000/1 was for increased participation in SERPS - up from 31 to 38 percent of workers, while the percentage with personal pensions stagnated at 28 percent. $^{49}$

Overall, the U.K. experience suggests that the issues confronted in designing and implementing opt-out pensions are quite daunting. Opt-out plans involve enormous complexity, require substantial information on the part of workers, and add to administrative costs, especially if the percentage of payroll involved is fairly small. And they are likely to offer most of their benefits to people with higher incomes. Indeed, the National Association of Pension Funds, the research and lobbying arm of occupational pension funds in the U.K., has recently proposed that policymakers in the U.K. consider separating the roles of a universal public pension and individual account tiers, requiring

\footnotetext{
${ }^{49}$ Pensions Policy Institute, Could Contracting Out Be Abolished?, PPI Briefing Note Number 12, July 2004, p. 2.
} 
the latter for all workers. ${ }^{50}$ Such a sorting out of public and individual account pensions is an idea worth considering in the United States as well.

${ }^{50}$ National Association of Pension Funds, Toward a Citizen's Pension: Interim Report, London: NAPF, December 2004 


\section{References}

Abrams, Fran. 1997. “Labour splits Over Serps Scheme.” The Independent (London), 8.

Anderson, Esping, Bonoli Pierson, and Helen Fawcett. 1995. "The Privatization of Welfare: The Impact of Parties on the Public/Private Mix in Pension Provision." West European Politics. 18(4): 150-169.

Age Concern. 2003. The State Pension. Fact Sheet 19, FS/19/03/04/01AM005.

Ashworth, Anne and Caroline Merrell. 1997. "Looking for a Bright Idea to Meet the Challenges of a Grey Future." The Times, London.

Budgetary Challenges Posed by Ageing Population. 2003. EPC/ECFIN/655/01_EN final, Table 3.5, reproduced in U.K. House of Commons, Works and Pensions Committee, The Future of U.K. Pensions, HC-92-1, Third Report of Session 2002-03, Volume 1: Report and Proceedings of The Committee, London: the Stationery Office Limited.

Crewe, Ivor. 2001. "Elections and Public Opinion,” 67-94.

Department for Work and Pensions. 2003. Her Majesty’s Treasury, and Inland Revenue. Simplicity, Security and Choice: Working and Saving for Retirement-Action on Occupational Pensions. London: Her Majesty's Stationery Office, Cm 5835.

Department of Social Security. 2000. Fact Sheets on Social Security: Second State Pension. http://www.dss.gov.uk/publications/dss/2000/fsheets/s2p.htm.

Disney, Richard, Carl Emerson and Sarah Tanner, and Emmerson and Tanner. 1999. Partnership in Pensions: A Commentary. Commentary No. 78. London: Institute for Fiscal Studies.

Duverger. 1963. Political Parties: Their Organization and Activity in the Modern State. London: Methuen.

Eastham, Paul. 2000. “The Astonishing Cost of Sorting Out Whitehall Pensions Mix-up.” Daily Mail (London), 13.

Elliott, Larry. 2000. "Hero or Villain? Brown Faces a Means Testing Time in Dilemma Over Pensions." The Guardian, 23.

Evans, Brendan. 1999. Thatcherism and British Politics 1975-1999. Gloucestershire: Sutton, Chapter 1.

Fowler, Reform of Social Security, vol. 1, 22-23.

Francis, Clare and Adam Jaques. 2003. "In? Out? The People Who Left SERPS Are Shaken All About." Independent on Sunday, 12.

Francis, Clare. 2003. "Savers Told to Opt Back Into State Pension System.” Sunday Times. Money section, 4.

Geddes, Anthony and Jonathan Tonge. 1997. Labour's Landslide. Manchester: Manchester University Press.

Ginn, Jay and Sara Arber. 1999. "The Politics of Old Age in the UK." In Alan Walker and Gerhard Naegele, eds., The Politics of Old Age in Europe, Buckingham and Philadelphia: Open University Press, 152-167. 
Glennerster, Howard. 2000. British Social Policy Since 1945 [second edition]. Oxford: Blackwell, Chapter 4.

Grofman, Bernard, and Arend Lijphart. 1986. Electoral Laws and their Political Consequences. New York: Agathon.

Hacker, Jacob S. 2004. "Privatizing Risk without Privatizing the Welfare State: The Hidden Politics of Social Policy Retrenchment in the United States." American Political Science Review, 98(2).

Harrington, Anthony. 2002. "Modest Green Paper Proposals Gain Mild Instustry Approval." The Scotsman, 25.

Hazell, Ton. 2003. "Pensions Chaos Too Confusing.” Daily Mail. 54.

Heclo, Hugh. 1974. Modern Social Politics in Britain and Sweden: From Relief to Income Maintenance. New Haven and London: Yale University press, 158-178.

Hennessy, Patrick. 1997. "Opposition Split as Kewy MP Praises Tory Pension Plans.” Evening Standard (London), 6.

Hibbs, Jon. 1997. “Company Pension Schemes ‘At Risk’ Under Lilley Plan.” Daily Telegraph, 12.

Jamieson, Bill. 2002. "Moving Out of the Pensions Morass." The Scotsman, 9.

Jones, Rupert. 2002. Funds Push Universal Citizen’s Pension. The Guardian, 24.

Kavanaugh, Dennis. 1997. The Reordering of British Politics: Politics After Thatcher. Oxford: Oxford University Press, Chapters 2-5.

Kavanaugh, Dennis. 2000. “Elections.” Harlow, Essex: Longmans, 143-161.

Levin, Peter. 1997. Making Social Policy. Buckingham and Philadelphia: Open University Press, Chapter $7,144-147$

Munnell, Alicia H. and Mauricio Soto. 2005. What Does Price Indexing Mean for Social Security Benefits? Center for Retirement Research at Boston College. Just The Facts on Retirement Issues, Number 14.

National Association of Pension Funds. 2002. Pensions_Plain and Simple. London: NAPF.

National Association of Pension Funds. 2004. Toward a Citizen's Pension: Interim Report. London: NAPF.

Palmer, Richard. 2003. "Pensions Blow to Middle Classes.” Daily Express, 1.

Pensions Commission. 2004. Pensions: Challenges and Choices. London: Her Majesty's Stationery Office, Figures 1.6, 1.7, 2.9-2.12.

Pensions Service. 2002. State Pensions: Your Guide, 3-6.

Pensions Policy Institute. 2004. Could Contracting Out Be Abolished? PPI Briefing Note Number 12, 2.

Pension Service. 2002. Personal Pensions-Your Guide, 7.

Pierson, Paul. 2001. Dismantling the Welfare State? The Politics of Retrenchment in Britain \& The United States. Cambridge University Press, 60. 
Prestridge, Jeff. 2002. “Our Three Wishes... and How They Could Tackle Britain's Pension Crisis.” Mail on Sunday, 13.

Pridham, Helen. 2003. “Should I stay Out or Should I Contract Back In?” The Times. Money section, 7.

Rawnsley, Andre. 2000. Servants of the People: The Inside Story of New Labour. London: Hamish Hamilton, 5, 120.

Ross, Sarah. 2002. "Big Challenges for Low-Paid, Part Timers." Financial Times [London edition]. FT Money, p.3.

Secretary of State for Social Services. Reform of Social Security. London: Her Majesty's Stationery Office, 9517(2): 2-3, 6, 21.

Secretary of State for Social Services. 1985. Reform of Social Security:Programme for Action. London: Her Majesty's Stationery Office, 9691, 12.

Secretary of State for Social Services. 1986. Social Security Bill 1986:Report by the Government Actuary on the Financial Effects of the Bill on the National Insurance Fund. London: Her Majesty's Stationery Office, 9711.

Secretary of State for Social Security. 1998. A New Contract for Welfare: Partnership in Pensions, Cm. $4179,18$.

Seddon, Anthony. The Blair Effect: The Blair Government,1997-2001. London: Little Brown.

Sparrow, Andrew. 2000. "Darling Refuses to Raise SERPS Payout.” Daily Telegraph (London), 10.

Steed, Allison. 2003. “ABI Weighs Into State Pensions.” Daily Telegraph, 36.

Tassell, Tony. 2003. “Tories Want All Employees in Company Plans.” Financial Times, 4.

The Divided Welfare State: The Battle over Public and Private Social Benefits in the United States. Cambridge: University Press.

The State of Dependency: Welfare Under Labour. 2000. London: Social Market Foundation.

Timmins, Nicholas. 2003. "Call for Changes to State Pension System.” Financial Times, 8.

Tsebelis, George. 1990. Nested Games: Rational Choice in Comparative Politics. Berkeley and Los Angeles: University of California Press, Chapter 5.

Weaver, R. Kent, and Bert Rockman. 1993. Do Institutions Matter? Washington, DC: The Brookings Institution.

Wilson, Graeme and Dareen Behar. 2002. "Save More or Work Beyond Age of 65.” Daily Mail, 1.

Womack, Stephen. 2002. "Plight of the 4.5 million Women Trapped by 'Biggest Pension Scandal Ever." Mail on Sunday, 26. 


\section{RECENT WORKING PAPERS FROM THE \\ CENTER For RETIREMENT ReSEARCH AT Boston COLlEge}

Cross-National Evidence on the Burden of Age-Related Public Transfers and Health Benefits

Gary Burtless, February 2006

Population Aging and the Structure of Wages

Bob Triest, Steven Sass and Margarita Sapozhnikov, February 2006

Financing Disability Benefits in a System of Individual Accounts: Lessons from International Experience

Patrick Wiese, February 2006

Long-Term Immigration Projection Methods: Current Practice and How to Improve it

Neil Howe and Richard Jackson, February 2006

Policies to Promote Labor Force Participation of Older Workers

Alicia H. Munnell, January 2006

Private Transfers in a Cross Section of Developing Countries

Donald Cox, Emanuela Galasso and Emmanuel Jimenez, January 2006

Making Maximum Use of Tax-Deferred Retirement Accounts

Janette Kawachi, Karen Smith and Eric Toder, January 2006

When the Nest Egg Cracks: Financial Consequences of Health Problems, Marital Status Changes, and Job Layoffs at Older Ages.

Richard W. Johnson, Gordon B.T. Mermin and Cori E. Uccello, December 2005

How Portfolios Evolve after Retirement: the Effect of Health Shocks.

Courtney Coile and Kevin Milligan, December 2005

Demographic Interactions between North and South and the Implications for North-South Capital Flows

Ralph C. Bryant, December 2005

The Decline in Household Savings: What can we learn from Survey Data?

Barry Bosworth and Lisa Bell, December 2005

All working papers are available on the Center for Retirement Research website

(http://www.bc.edu/crr) and can be requested by e-mail (crr@bc.edu) or phone (617-552-1762). 